\title{
PENERAPAN MODEL PEMBELAJARAN DARING GOOGLE CLASSROOM, GOOGLE MEET DAN INSTAGRAM DALAM MENINGKATKAN KEAKTIFAN BELAJAR SISWA SAAT PANDEMI COVID 19 DI SMA NEGERI 1 CANDIROTO
}

\author{
DWI WINARNI INDRAWATI
}

SMA Negeri 1 Candiroto Temanggung

Email : indrawatidwi489@gmail.com

\begin{abstract}
ABSTRAK
Penelitian ini bertujuan untuk mengetahui peningkatan keaktifan belajar dalam pembelajaran daring melalui media Google Classroom, Google Meet, Instagram. Penelitian ini merupakan penelitian tindakan kelas dengan subyek penelitian siswa kelas XII IPS2 SMA N 1 Candiroto sebanyak 32 orang. Penelitian ini dilaksanakan 2 siklus, masing-masing siklus 2 kali pertemuan. Setiap pertemuan terdisi dari 4 tahap yaitu perencanaan, pelaksanaan, observasi dan refleksi. Pelaksanaan tahap-tahap penelitian sedikit berbeda dari pembelajaran dalam kelas karena pembelajara dilakukan secara terpisah atau siswa berada dirumah masing-masing. Berdasarkan hasil penelitian, pada siklus I diperoleh rata-rata siswa yang aktif 57,9\% dengan katagori cukup. Sedangkan pada siklus II diperoleh rata-rata siswa aktif 74,7 \% dengan katagori tinggi. Jadi dari siklus I dan siklus II terjadi peningkatan keaktifan siswa 16,8\%. Dengan demikian penelitian dapat disimpulkan bahwa media Google Classroom, Google Meet dan Instagram dapat meningkatkan keaktifan siswa dalam pembelajaran daring pada masa pencegahan penyebaran Covid-19 mata pelajaran PPKn.
\end{abstract}

Kata kunci : pembelajaran daring google classroom,google meet, keaktifan siswa

\section{PENDAHULUAN}

Belajar merupakan proses pendidikan di sekolah yang bertujuan untuk menghasilkan perubahan tingkah laku.Perubahan meliputi kognitif, afektif, psikomotor. Diperlukan keaktifan ,partisipasi dan komunikasi yang efektif antara guru dan siswa. Keberhasilan dalam proses pembelajaran dapat dilihat dari pemahaman konsep,penguasaan materi dan prestasi belajar. Menurut Mulyansa (2002:32) keaktifan siswa dalam pembelajaran sangatlah penting .Pembelajaran dikatakan berhasil dan berkualitas apabila seluruhnya atau setidaknya sebagian peserta didik terlibat secara aktif, baik fisik, mental maupun sosial dalam proses pembelajaran.Pendidikan pada era revolusi industri 4.0 memiliki tantangan yang besar .Guru harus mampu berinovasi untuk meningkatkan motivasi dan keaktifan siswa dalam belajar .Peningkatan mutu salah satunya dapat dilakukan melalui pembaharuan media pembelajaran.Sekolah sebagai penghasil sumber belajar manusia harus mampu meningkatkan kualitas agar lulusannya memiliki kemampuan berdaya saing tinggi.

Pada tahun 2019, Dunia dikejutkan dengan munculnya wabah Corona virus.Wabah tersebut pertama kali terdeteksi di kota Wuhan, China yaitu tepatnya dipasar Seafood Huanan. Setelah dilakukan penelitian penyakit tersebut disebabkan oleh virus, yang lebih dikenal dengan Corona virus Diseases 2019 (COVID 19). Corona virus Diseases 2019 ini sebelumnya belum pernah menjangkit manusia. gelaja umum terinfeksi COVID 19 antara lain gejala gangguan pernapasan akut seperti demam, batuk, dan sesak napas. Bagi dunia pendidikan menuntut untuk tetap bisa menyelenggarakan pendidikan bagi peserta didik walau dengan Pembelajaran Jarak Jauh, sebagaimana tercantum dalam Surat Edaran Mendikbud Nomor 4 Tahun 2020 (Direktorat sekolah menengah pertama kementerian pendidikan dan kebudayaan, 2020) tentang Pelaksanaan Kebijakan Pendidikan dalam Masa Darurat Penyebaran Covid-19 bahwa proses Belajar dari Rumah (BDR) melalui Pembelajaran Daring/ Jarak Jauh (PJJ) yang dilaksanakan untuk memberikan pengalaman belajar yang bermakna bagi siswa, tanpa terbebani tuntutan menuntaskan seluruh capaian kurikulum untuk kenaikan kelas maupun kelulusan.

Kondisi yang dipaparkan di atas, memberikan dorongan atas pencapaian tujuan 
pembelajaran, Subjek utama dalam pembelajaran terdiri dari tiga hal (Tritiyatma, et al., 2017) yaitu: 1) Terampil belajar dan berinovasi; 2) Terampil menggunakan informasi, media, dan teknologi; dan 3) Terampil untuk hidup dan berkarir. Penyesuaian tujuan pembelajaran tersebut dengan kondisi pandemi Covid-19 memiliki kesamaan secara dasar yaitu berfokus pada pembelajaran berbasis TIK. Melibatkan TIK secara efektif dan efisien dalam proses pembelajaran akan mendukung revolusi pendidikan (Sukmawati, 2020).Pembelajaran berbasis TIK dapat diimplementasikan dengan berbagai pendekatan, salah satunya melalui pembelajaran selular atau mobile learning (m-learning). Mobile learning merupakan pembelajaran bergerak yang dapat dilakukan dimana dan kapanpun oleh siswa tanpa adanya batasan waktu maupun tempat dan menggunakan teknologi mobile (Claire, 2003). M-learning dapat mengubah mobile phone memiliki fungsi tambahan muatan pelajaran yang semula hanya digunakan untuk telepon, sms, dan internet menjadi perangkat untuk alat belajar yang lengkap (Yuniati, 2011). Pencapaian kognitif, psikomotorik, dan karakter siswa dalam penelitian ini dapat diperoleh dengan pengintegrasian metode selama proses pembelajaran $\mathrm{m}$ - learning dengan melalui pembelajaran berbasis TIK untuk meningkatkan keaktifan belajar siswa .

Berdasarkan hasil observasi, siswa SMA Negeri 1 Candiroto memerlukan adaptasi yang tinggi dalam melaksanakan pembelajaran jarak jauh. Diperlukan kerjasama yang baik di era pembelajaran jarak jauh antara sekolah, siswa, dan orang tua demi keberhasilan pembelajaran jarak jauh di SMA Negeri 1 Candiroto. Dalam pelaksanaan pembelajaran jarak jauh, tingkat keaktifan peserta didik menurun drastis dibandingkan pada saat pembelajaran tatap muka. Hal ini dibuktikan dengan penurunan prosentase keaktifan dan kehadiran pembelajaran jarak jauh, dibandingkan dengan pembelajaran tatap muka di sekolah.Selain itu penggunaan media Whats App memberikan kejenuhan kepada siswa dalam belajar. Kegiatan guru yang dapat meningkatkan keaktifan siswa menurut Moh. Uzer Usman (2009: 26-27) yaitu memberikan motivasi, menjelaskan tujuan instruksional, mengingatkan kompetensi belajar, memberikan stimulus (masalah, topik, konsep), memberikan petunjuk cara mempelajari, memberikan umpan balik, dan menyimpulkan di akhir pembelajaran. Keaktifan dapat ditingkatka dan diperbaikan dalam keterlibatan siswa pada saat belajar.

Menghadapi beberapa masalah atau tantangan dalam pembelajaran jarak jauh, guru dituntut untuk dapat menciptakan pembelajaran yang menyenangkan, menarik dan aktif. Walaupun pembelajaran dilaksanakan jarak jauh atau daring, guru harus mampu meningkatkan keaktifan siswa. Keaktifan siswa dapat tercipta melalui penerapan media pembelajaran. Menurut Gagne dan Briggs (dalam Martinis, 2007) Pembelajaran berbasis TIK dapat diimplementasikan dengan berbagai pendekatan, salah satunya melalui pembelajaran selular atau mobile learning (m-learning). Mobile learning merupakan pembelajaran bergerak yang dapat dilakukan dimana dan kapanpun oleh siswa tanpa adanya batasan waktu maupun tempat dan menggunakan teknologi mobile (Claire, 2003). M-learning dapat mengubah mobile phone memiliki fungsi tambahan muatan pelajaran yang semula hanya digunakan untuk telepon, sms, dan internet menjadi perangkat untuk alat belajar yang lengkap (Yuniati, 2011). Pencapaian kognitif, psikomotorik, dan karakter siswa dalam penelitian ini dapat diperoleh dengan pengintegrasian metode selama proses pembelajaran. Adapun platform pembelajaran daring yang dapat digunakan yaitu google classroom dan google meet. Tidak hanya itu penggunaan media sosial umumnya juga dapat dijadikan sebagai learning tools, salah satunya yaitu instagram.

Google classroom yaitu aplikasi yang menggunakan jaringan internet dengan menggunakan computer dan/atau handphone (Hakim, 2016). Google classroom dapat mengaktifkan siswa pada proses pembelajaran disebabkan media ini dapat menampilkan teks, gambar, dan video pada saat proses pembelajaran berlangsung. Selain itu, aplikasi ini dapat 1) menyederhanakan kegiatan membuat, mendistribusikan, dan menilai tugas siswa tanpa harus bertatap muka langsung (Mahayoni, 2020; Okmawati, 2020); 2) melakukan percakapan tentang tugas dan guru dapat mengetahui kemajuan siswa (Beal, 2020); 3) menjadi media interaksi antara guru dengan siswanya atau siswa dengan siswa lainnya (Liu \& Chuang, 2016); dan 4) 
menampung dan mengatur waktu pengumpulan tugas oleh guru yang akan menumbuhkan rasa kedisiplinan dan tanggung jawab bagi siswa dalam mengerjakan tugas.

Google Meet adalah layanan panggilan video utama Google yang diluncurkan pertama kali pada tahun 2017. Ketersediaan Google Meet dapat memberikan solusi potensial dalam proses pembelajaran.Google Meet memiliki pengaruh yang sangat tinggi terhadap minat belajar siswa karena mudah digunakan, waktu yang fleksibel, dan dapat dilaksanakan dimana pun siswa berada (Septantiningtyas, 2020). Tautan Google Meet yang disediakan dalam setiap waktu kelas dapat digunakan beberapa kali yang memungkinkan siswa untuk terhubung dengan guru kapan saja (Al-Maroof, R.S., et al., 2020). Manfaat menggunakan Google Meet dibanding layanan lain adalah kesederhanaannya hanya dengan memiliki akun Google, selanjutnya langsung dapat memulai panggilan Pemanfaatan platform google classroom dan google meet sangat membantu dalam pelaksanaan pembelajaran jarak jauh. Penggunaan teknologi mempunyai sumbangan besar dalam lembaga pendidikan, termasuk di dalamnya adalah pencapaian tujuan pembelajaran jarak jauh (Korucu \& Alkan, 2011) .

Instagram adalah salah satu aplikasi media sosial populer di kalangan pelajar untuk berbagi foto dan video. Instagram merupakan aplikasi sosial media yang sangat tepat digunakan sebagai media pembelajaran. Guru dapat secara aktif terhubung dengan siswanya (Zhang, 2013). Media ini juga memungkinkan adanya kolaboratif antara guru dan siswa dalam suatu tugas proyek pembelajaran (Bexbeti, 2014). Siswa dapat terlatih untuk mengkomunikasikan hasil karyanya kepada masyarakat luas dengan cara membagikannya pada akun masing-masing. Rasa tanggung jawab siswa juga akan terbangun karena terdapat dorongan untuk menyusun hasil karya yang baik. Pada media sosial ini karya siswa akan dinilai oleh banyak orang.

Penelitian ini bertujuan untuk mengajukan inovasi metode pembelajaran during untuk mencapai kognitif, psikomotorik, dan karakter siswa berbasis TIK. Media yang dimaksud yaitu google classroom, google meet, dan instagram. Dengan penerapan tersebut, diharapkan mobile learning mampu menjadi alternatif dalam pembelajaran during pada pandemi ini sehingga dapat meningkatkan aktifitas siswa dalam belajar.

\section{METODE PENELITIAN}

Metode penelitian yang digunakan dalam penelitian ini adalah penelitian tindakan kelas.Untuk meningkatkan keaktifan siswa dalam pembelajaran daring melalui media penerapan pembelajaran daring Google Classroom,Google Meet dan Instagram pada masa pencegahan penyebaran Covid-19 mata pelajaran PPKn .Penelitian ini dilakukan pada materi Kasus kasus pelanggaran hak dan pengingkaran kewajiban . Subyek penelitian adalah siswa kelas XII IPS 2 yang melibatkan 32 siswa. Penelitian dilakukakan sejak dimulaianya belajar dirumah sejak tanggal 17 Juli sampai tanggal 27 Agustus tahun 2021. Instrumen pengumpulan data adalah lembar observasi pelaksanaan proses pembelajaran daring melalui google Classroom , Google Meet dan Instagram sedangkan teknis analisis data menggunakan teknik analisis deskriptif kualitatif dan kualitatif menggunakan kreteria pencapaian

\section{HASIL DAN PEMBAHASAN}

Penelitian ini dilaksanakan 2 siklus yaitu siklus I dan siklus II masing masing siklus ada 2 kali pertemuan. Tahapan penelitian yang dilakukan pada siklus I pertemuan ke-1 adalah (1) tahap perencanaan yaitu menyiapkan lembar observasi dan menyusun naskah soal untuk kuis, (2) tahap pelaksanaan yaitu memberikan file materi melalui whatsapp grup, mengintruksikan dan membimbing penguduhan aplikasi,memberikan kode kuis, (3) tahap observasi mengunduh hasil pekerjaan siswa, (4) refleksi. Tahap tahap ini juga dilakukan untuk pertemuan yang ke-2. Tahap-tahap penelitian ini sedikit berbeda karena pembelajaran bukan dalam kelas atau pembelajaran secara klasikal melainkan secara terpisah atau siswa berada dirumah masingmasing. Berdasarkan hasil observasi pertemuan ke-1 dari 32 siswa hanya $18(56,3 \%)$ orang yang aktif, hal ini dapat dilihat dari hasil unduhan siswa yang mengerjakan kuis 1. Pertemuan ke-2 siswa yang aktif mengerjakan kuis 2 sebanyak $19(59,4 \%)$ siswa .Pada siklus I pertemuan 
ke-1 dan ke-2 rata-rata 57,85\% yang aktif. Menurut Semiawan (1999) keaktifan belajar dapat ditunjukkan oleh siswa dalam kegiatan belajar.

Tabel 1. Katagori Tingkat Keatifan Belajar Siswa

\begin{tabular}{|c|l|l|}
\hline NOMOR & \multicolumn{1}{|c|}{ RENTANG SKOR } & \multicolumn{1}{c|}{ KATEGORI } \\
\hline 1 & $85-100$ & SANGAT TINGGI \\
\hline 2 & $69-84$ & TINGGI \\
\hline 3 & $53-68$ & CUKUP \\
\hline 4 & $37-52$ & RENDAH \\
\hline 5 & $20-36$ & SANGAT RENDAH \\
\hline
\end{tabular}

Jadi hasil observasi pada siklus I menurut katagori diatas adalah termasuk katagori cukup. Setelah hasil diketahui maka perlu dilakukan refleksi untuk mengkoreksi kelemahan dan kendala yang terjadi pada siklus I kemudian mencari solusi yang nanti akan diterapkan pada siklus II dengan harapan hasilnya mengalami peningkatan. Dalam pelaksanaan siklus II, guru melakukan langkah-langkah yang sama dengan langkah-langkah pada siklus I namun ada perbaikan pelaksanaan berdasarhan hasil refleksi pada siklus I. Berdasarkan hasil pertemuan ke-1 pada siklus II siswa yang aktif mengerjakan kuis 3 sebanyak $22(68, \%)$ siswa,sedangkan pada pertemuan ke-2 siswa yang aktif $26(81,3 \%)$ siswa.Rata-rata hasil observasi pada siklus II adalah 74,7\% .Hasil siklus II termasuk dalam katagori tinggi. Dari hasil observasi suklus I dan siklus II keaktifan siswa mengalami peningkatan sebesar 17,65\%. Berikut tabel rekapitulasi keaktifan siswa kelas XII IPS 2 pada siklus I dan siklus II.

Tabel 2. Rekapitulasi Hasil Observasi Keaktifan Siswa

\begin{tabular}{|c|c|c|c|c|c|c|c|}
\hline \multirow{2}{*}{ Siklus } & \multirow{2}{*}{$\begin{array}{c}\text { Jumlah } \\
\text { siswa }\end{array}$} & \multicolumn{2}{|c|}{$\begin{array}{c}\text { Jumlah siswa yang } \\
\text { mengerjakan tugas }\end{array}$} & \multicolumn{2}{|c|}{ prosentase } & \multirow{2}{*}{$\begin{array}{c}\text { Rata- } \\
\text { rata }\end{array}$} & Kategori \\
\cline { 3 - 7 } & & P.1 & P.2 & P.1 & P.2 & & \\
\hline 1 & 32 & 18 & 19 & $56.3 \%$ & $59,4 \%$ & $57,9 \%$ & CUKUP \\
\hline 11 & 32 & 22 & 26 & $68 \%$ & $81,3 \%$ & $747 \%$ & TINGGI \\
\hline
\end{tabular}

Berdasarkan table 2 diatas maka dapat digambarkan pada grafis sebagai berikut

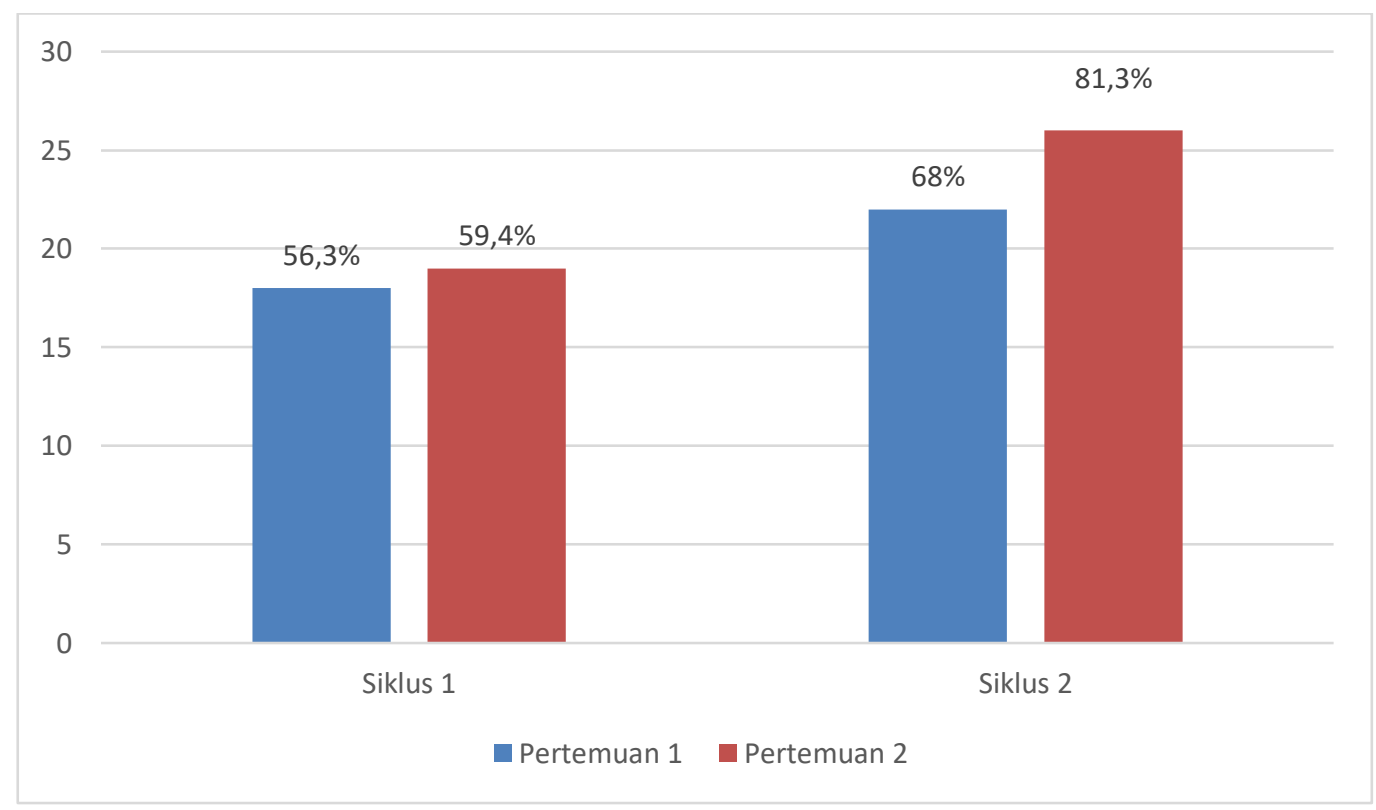

Grafik 1. Rekapitulasi Hasil Observasi Keaktifan Siswa

Media Google classroom,Google Meet dan Instagram dapat meningkatkan keaktifan 
siswa pada masa pencegahan penyebaran Covid-19 mata pelajaran PPKn karena dalam pelaksanaanya seolah-olah membawa pengaruhdalam aktivitas belajar dan membuat pembelajaran lebih interaktif yang menyenangkan sehingga setiap siswa aktif dalam pembelajaran .Walaupun belum 100\% siswa kelas XII IPS 2 melakukan pembelajaran daring karena ada beberapa kendala yang penyelesaianya perlu dilakukan kerjasama antara sekolah, orang tuasiswa, komite, dinas terkait dan steakholder.

\section{KESIMPULAN}

Simpulan yang diperoleh dari penelitian ini adalah terdapat peningkatan keaktifan siswa dalam pembelajaran daring melalui media clasroom,google Meet dan Instagram pada masa pencegahan penyebaran Covid-19 mata pelajaran PPKn kelas XII IPS 2 di SMA Negeri 1 Candiroto semester ganjil tahun pelajaran 2021/2022. Setelah pelaksanaan pembelajaran daring melalui media Classroom,Meet dan Instagram pada siklus I diperoleh rata-rata siswa yang aktif 57,9\% dari 32 siswa, sedangkan siklus II diperoleh rata-rata 74,7\%. Jadi, media Classroom,Meet dan Instagram dalam pembelajaran daring dapat meningkatkan keaktifan siswa pada masa pencegahan penyebaran Covid-19 mata pelajaran PPKn kelas XII IPS2. sebesar $16,8 \%$.

\section{DAFTAR PUSTAKA}

Arifin, Z. (2011). Evaluasi Pembelajaran - Prinsip Teknik Prosedur. Bandung: PT Remaja Rosdakarya.

Aryani, D., Malabay, M., Ariessanti, H. D., \& Putra, S. D. (2020). Pelatihan Pemanfaatan Google Classroom untuk Mendukung Kegiatan Pembelajaran Daring saat Pandemi COVID 19 di SMPIT Insan Rabbani. Jurnal Abdidas, 1(5),

Ashadi, N. R., \& Suhaeb, S. (2020). Hubungan Pemanfaatan Google Classroom dan Kemandirian terhadap Hasil Belajar Mahasiswa PTIK pada Masa Pandemi. Jurnal Media Elektrik, 17(2), 46-51.

Beal, V. (2020). Google Classroom. Editor of webopedia

Efendi, S \& Marpaung, R. F. (2018). Implementasi Mobile Learning Dengan Model Advance Organizer Dalam Meningkatkan Kemampuan Kognitif Kimia Mahasiswa. PeTeKa Jurnal Penelitian Tindakan Kelas dan Pengembangan Pembelajaran, 1(3): 171-178.

Febriyanti, R. H., \& Sundari, H. (2020). Penerapan Penggunaan Platform Dalam Pengajaran Bahasa Inggris Berbasis Daring. RANGKIANG: Jurnal Pengabdian Pada Masyarakat, $2(1), 17-27$.

Febriyanti, R. H., \& Sundari, H. (2020). Penerapan Penggunaan Platform Dalam Pengajaran Bahasa Inggris Berbasis Daring. RANGKIANG: Jurnal Pengabdian Pada Masyarakat, 2(1), 17-27.

Hakim, A. B. (2016). Efektifitas Penggunaan E-Learning Moodle, Google Classroom dan Edmodo. I-Statement, 2(1), 26.

Korucu, A. T., \& Alkan, A. (2011). Differences between m-learning (mobile learning) and elearning, basic terminology and usage of m-learning in education. Procedia - Social and Behavioral Sciences. https://doi.org/10.1016/j.

Liu, H. C., \& Chuang, H. H. (2016). Integrating Google Classroom to Teach Writing in Taiwan. Minnesota eLearning Summit

1-Maroof, R.S., et al. (2020): Fear from COVID-19 and technology adoption: the impact of Google Meet during Coronavirus pandemic. Interactive Learning Environments, 1-16.

Mahayoni, N. M. S. (2020). Penggunaan Aplikasi Zoom Meeting PadaPembelajaranAgama Hindu Di Masa Pandemi. Jurnal Widya Sastra Pendidikan Agama Hindu, 3(1), 47-53.

Mulyasa. (2004). Kurikulum Berbasis Kompetensi: Konsep, Karakteristik dan Implementasi. Bandung: Remaja Rosdakarya 
Naserly, M. K. (2020). Implementasi Zoom, Google Classroom, Dan Whatsapp Group Dalam Mendukung Pembelajaran Daring (Online) Pada Mata Kuliah Bahasa Inggris Lanjut. EDUTECH CONSULTANT BANDUNG Jurnal AKSARA PUBLIC, 4(2): 155-165.

Nurkamid, M., Dahlan, M., Susanto, A., \& Khotimah, T. (2010). Pemanfaatan aplikasi jejaring sosial facebook untuk media pembelajaran. Sains dan Teknologi, 3(2), 1-16.

Pradana, D. B. P. (2017). Pengaruh Penerapan Tools Google Classroom Pada Model Pembelajaran Project Based Learning Terhadap Hasil Belajar Siswa. IT-Edu: Jurnal Information Technology and Education, 2(1)

Sawitri, D. (2020). Penggunaan Google Meet Untuk Work from Home Di Era Pandemi Coronavirus Disease 2019 (Covid-19). Prioritas: Jurnal Pengabdian Kepada Masyarakat, 2(01), 13-21.

Septantiningtyas, N., et al. (2020). Implementation of Google Meet Application in the Learning of Basic Science in the Covid-19 Pandemic Period of Student Learning Interests. 2nd Bukittinggi International Conference on Education (BICED), Journal of Physics: Conference Series, 1-6.

Tritiyatma, T. (2017). Keterampilan Abad 21 Dan Steam (Science, Technology, Engineering, Art and Mathematics) Project Dalam Pembelajaran Kimia. Republik Indonesia: Kementerian Hukum dan Hak Asasi Manusia, Direktorat Jenderal Kekayaan Intelektual u.b. Direktur Hak Cipta dan Desain Industri.

Utami, R. P., Probosari, R. M., \& Fatmawati, U. M. I. (2015). Pengaruh Model Pembelajaran Project Based Learning Berbantu Instagram Terhadap Kemampuan Berpikir Kreatif Siswa Kelas X SMA Negeri 8 Surakarta. Bio-Pedagogi, 4(1), 47-52..

Wicaksono, V.D., Rachmadyanti, P., 2018. Pembelajaran Blended Learning Melalui Google Classroom di Sekolah Dasar. Presented at : Seminar Nasional Pendidikan PGSD UMS \& HDPGSDI Wilayah Jawa. pp. 513-520

Zhang, L. 2013. Mobile phone technology engagement in EFL classroom. International Conference on Software and Computer Science (ICSECS): 171-173. 